This is a post-print (i.e. final draft post-refereeing) version of the paper:

Van Daele, S., Vander Beken, T., \& Bruinsma, G. (2012). Does the mobility of foreign offenders fit the general pattern of mobility? European Journal of Criminology, 9(3), 290-308.

The sole and exclusive right to publish this paper has been granted to the European Society of Criminology.

The paper can be accessed online at: http://euc.sagepub.com/content/9/3/290 


\title{
Does the mobility of foreign offenders fit the general pattern of mobility?
}

\begin{abstract}
Research on offender mobility is directed to three main elements: distance, anchor points, and direction. Previous research in geographic criminology revealed that: (1) the journey to crime is limited in distance and follows a distance decay pattern; (2) the home of the offender plays a central role as the starting point of crime trips; and (3) the direction of their trip influenced by the opportunities to commit their crimes. The findings are more or less accepted as 'laws' in the field. However, research on offender mobility is often limited by its method, data and sample of arrested offenders. This study investigated in contrast a sample of arrested foreign offenders (East-Europeans) who stayed temporarily in Belgium. They lack the spaceawareness and routine activities of residential offenders. Using multiple methods and data including police statistics, case file analysis and offender interviews, we investigated the travelling patterns of these offenders both quantitatively and qualitatively. The findings demonstrated that: (1) the degree of distance decay is much more moderate than generally found in the literature; (2) the official living address plays hardly any role at all as an anchor point; and (3) these offenders travel outward opportunity structures that are different from routine activities patterns of Belgium offenders. Overall, our findings indicate that offender mobility does not fit the accepted general pattern or 'laws' as assumed in previous research.
\end{abstract}




\section{Introduction}

Empirical research on offender mobility is directed to three elements of the journey to crime (Rengert, 2004): (1) a departure point in space from where offenders start their journey, (2) the direction they move, and (3) the distance they travel to the spot where they commit their crimes. Various theories have been suggested to explain the journey to crime, among them the crime pattern theory (Brantingham and Brantingham, 1993a, 1995; Brantingham and Brantingham, 2008); routine activity theory (Felson, 1986, 2008; Felson and Cohen, 1980); rational choice theory (Cornish \& Clarke, 1986; Elffers, 2004); foraging theory of behavioural ecology (Bernasco, 2009) and opportunity theory (Bottoms and Wiles, 1992; Eck and Weisburd, 1995; Wilcox, Land, and Hunt, 2003).

Unfortunately, empirical research on offender mobility is often limited by its method, data and its samples of arrested offenders. Most offenders are familiar to police (usual suspects), especially when street crimes or offences such as residential burglary are involved. Studies indicate that 70-80 per cent of all registered crimes are committed by residents within their own city or village (Wiles and Costello, 2000). In The Netherlands, only 2-3 per cent of all registered crimes are connected to foreigners who stayed there temporarily (Bruinsma, 1999), and in England and Wales this percentage is even lower (Porter, 1996; Wiles and Costello, 2000). Consequently, foreign offenders are underrepresented in all registered crime data.

Another methodological drawback of police files is that many case files lack factual information about the starting point of the journey to crime. In this situation, researchers have assumed - without further empirical evidence - that the residence of the offender is the starting point in the mapping offender mobility. This leads to an overestimation of the importance of offenders' residences. Despite the methodological drawbacks, similar research 
outcomes have been replicated in countries and cities all over the world and therefore have been accepted as established 'facts' in geographic criminology.

In this study, we challenge these established findings by studying the mobility of foreign offenders who stayed in Belgium temporarily. Such offenders have only rarely been researched in geographic criminology. Using multiple data from a sample of East-European offenders arrested in Belgium, we inquire into three elements of offender mobility.

\section{The elements of offender mobility in more detail}

\section{Distance (decay)}

In the first half of the twentieth century, White (1932) demonstrated that offenders take little effort to travel and carry out their crimes at locations near their homes. The findings of his pioneering work were confirmed later that century by several others (see, for example, Capone and Nichols, 1975; Hesseling, 1992; Phillips, 1980; Reppetto, 1974; Rhodes and Conly, 1981). More recently, scholars have extended this finding to reveal the existence of a 'distance decay' function. This function prescribes that most offences are committed near home-addresses of the offender and that the number of crimes diminishes as the distance from home increases (for example, Bernasco, 2006; Canter and Youngs, 2008a; Phillips, 1980;

Rattner and Portnov, 2007; Rengert, Piquero, \& Jones, 1999; Turner, 1969; Van Koppen and Jansen, 1998).

Despite the general observation of the distance decay pattern, there has been a debate whether this pattern is only observed at the aggregate level or at the level of the individual offender. Although this discussion was rather abstract at first (Rengert et al., 1999; Van Koppen and De Keijser, 1997), recent empirical research has shown that a large amount of variation in offending patterns exists between offenders and only to a lesser extent within 
offenders (Smith, Bond, and Townsley, 2009; Townsley and Sidebottom, 2010; Van Daele, 2010).

\section{Anchor points}

In order to calculate a journey to crime, information of a starting point and a terminus are needed. Information about the terminus, or crime site, can be found for the most part in official data. But the starting point of the criminal's home-address has been assumed. Some have elevated this to the status of a principle and named it 'domocentricity' (Canter and Gregory, 1994; Canter and Larkin, 1993; Sarangi and Youngs, 2006). The centrality of the home-address enables researchers to successfully develop a geographic profile. With this technique, the location of the crime scenes is used to derive an offender's most likely activity space or starting area. This often refers to the home area (Canter, 2003; Canter and Youngs, 2008a; Kocsis, Cooksey, Irwin, and Allen, 2002; Rossmo, 1995, 2000; Rossmo and Rombouts, 2008). Wiles and Costello (2000) observed that offenders regularly start their crime trips at other locations, friends' homes, work or leisure activities. It is thus also demonstrated empirically that a crime trip is not always beginning at home but in bars, shops, friends' homes, bus stations or schools.

\section{Direction}

Rengert refers to direction as 'heading towards certain areas' (Rengert, 2004: 171-172). Pyle et al. (1974) consider city centres as outstanding opportunity structures. The notification of criminal opportunities depends on daily routines of people. Both routine activity theory (Cohen and Felson, 1979; Felson and Cohen, 1980) and pattern theory stress the importance of criminal opportunities (Brantingham and Brantingham, 1981, 1993b). Routines of potential 
victims create opportunity structures for motivated offenders, whereas everyday activities of offenders enable them to successfully exploit these opportunities.

Most of these findings have originated from research on local offenders: offenders with a residence and awareness of space within the target area. Yet, this is probably not the case for all offenders. Some will have only settled recently in a certain area, and will have yet to develop an extensive environmental knowledge about the setting. Bernasco (2010) found, for instance, that residential history plays an important role in criminal location choice. Offenders who have recently moved are still looking for criminal opportunities in the vicinity of their previous residency. Consequently, offenders that are not permanent residents may be unaware of offending opportunities of that area. Our research examines the applicability of offender mobility principles on such a set of offenders. In particular, we pay attention to foreign offenders that come from Eastern Europe.

We propose to test three hypotheses: (1) the pattern of foreign offenders follows a distance decay curve; (2) foreign offenders start from their temporary residence; (3) foreign offenders, just as indigenous offenders, tend to travel toward criminal opportunity structures.

\section{Method and research sample}

Since 2004, the European Union has been extended towards the East, giving citizens from Eastern European nations increasing opportunities for 'borderless travel' to West-European countries for longer periods of time. As a consequence, thousands of migrants have moved to Western European countries to look for jobs, spend their holidays (the few well-to-do among them) or stay on a permanent basis. Some of them travel for other motives: to steal, to rob and to burglarize. In this study we focus on this last group, using three complementary methods to assess the offenders' mobility. 


\section{Police data}

Our quantitative approach uses police data. Such an approach connects the offender with the place of residence and the crime location, enabling us to calculate distances. The quantitative dataset contains all serious property crimes, that is, property crimes with aggravating circumstances, such as violence or intrusion, in Belgium for the years 2002 until 2006.

As mobility is offender-related, only those crimes with known offenders were selected (which is roughly 10 per cent of the total amount of crimes). Countries in Eastern Europe are located between 800 and $2000 \mathrm{~km}$ from Belgium. It is unlikely that daily crime trips are undertaken over such a distance. To avoid large error margins because of vague or mistaken information about residence, only registered residences in Belgium are considered (these may be temporary). This results in a dataset of over 67,000 crime-offender combinations or crime trips $(\mathrm{N}=67981 ; 51385$ by Belgian offenders, 7078 by Eastern European offenders and 9518 by other foreigners). As such, the main unit of analysis is offender-offence combinations or crime trips, which has been used by Hodgson and Costello (2006) as well. A substantial part of the database consists of multiple offenders (31 per cent). Hence, the database has a layered structure. The intra-class correlation coefficient (ICC) of .55 indicates that there is a resemblance of crime trips within individual offenders (Hox, 2010). As suggested by Townsley and Sidebottom (2010), this requires a multilevel approach. ${ }^{1}$

Given the nature of police data, crimes and residences are geocoded on the basis of the municipality in which they are located. The dataset contains both residences and crime locations, making it possible to calculate Euclidian crime distances. For crimes that end in another region than where they started, the distance between the centroids of both regions has been used. In cases where both the residence and the crime are located in the same municipality, we follow the method used by Bernasco (2006) and consider the covered

\footnotetext{
${ }^{1}$ A univariant General Linear Model was adopted in MLwiN, reformulating a one way ANOVA as a regression and using robust standard errors.
} 
distance half of the square root of the area (Ghosh, 1951). There are 589 municipalities in Belgium with an average area of $51.8 \mathrm{~km}^{2}(\operatorname{Min}=1.1$; $\mathrm{Max}=213.8$, S.D.=37.8).

In cases with co-offending, the trip for each offender has been calculated individually. Thus, if two offenders co-offend, two trips will be calculated: one from each residence to the crime location. Although both offenders may have met before at one of these residences, the data do not allow us to identify this actual starting point. Furthermore, relying only on this actual starting point would neglect the travelled distance and the spatial knowledge of the other offender involved, hence our decision to treat them as separate crime trips.

The dataset contains both crime (date, location) and offender (nationality, age) variables, but also variables with information on the locations (municipality coordinates, affluence index, population density). The strength of this method lies in the fact that a large both in actual size and in covered geographic area - sample is used and the data may therefore be quantitatively analysed. This method allows us to calculate the distances covered and the distance decay pattern of Eastern European offenders (hypothesis 1), the percentages of registered anchor points (hypothesis 2), and the main locations of offence targets (hypothesis 3). The main weakness of this method consists in the fact that only information on apprehended offenders is incorporated and that no in-depth information on the crime trip can be provided. One may analyse the distance between the municipalities, but that does not mean that offenders actually started from home or used the shortest route.

\section{Case files}

To compensate these weaknesses in data from police statistics, we added a twofold qualitative approach to the research and applied grounded theory principles. The first one is a case files analysis. We analysed 26 case files concerning Eastern European offenders. These case files were obtained from five distinct judicial districts that are quite diverse in location 
(from West to East), geography (both border regions and inland districts), size (smaller and larger areas) and building density (rural and urban areas). Given this diversity, these five districts function as a sampling frame, within which a selection of cases has been made, based on permissions and availability and involvement of Eastern European offenders. ${ }^{2}$ They refer to cases from the period 2000 to 2007 . Some offenders committed their crimes in a time span of three months, while others were active criminals for nearly three years (33 months). The offenders are responsible for various property crimes including residential burglaries, commercial burglaries and robberies, metal thefts and ram raids. The case files enable us to not only assess the target location, but also the starting point - which may not always coincide with the residence. Both in the choice of the police districts and in the choice of the actual case files, our analysis has sought a maximum degree of heterogeneity. Because of the great diversity however, the variety of cases helps to understand the differences in travelling to crime places. This method is mainly used to find out where these offenders start their crime trips, in other words, where their anchor points lie (hypothesis 2).

\section{Offender interviews}

In addition, we interviewed 21 Romanian offenders in prison in 2009. Criminals coming from Romania are, together with people coming from Albania and former Yugoslavia, the main group of Eastern European offenders in Belgium (FOD Justitie, FOD Kanselarij van de Eerste Minister, and FOD Binnenlandse zaken, 2007). The interviews were conducted with the help of an interpreter. This gave the respondents the possibility to answer questions in their mother tongue. Only convicted offenders were approached, as these persons have less reason to lie or conceal information about the crimes they have committed. Those interviewed were identified from a selection of suitable respondents $(\mathrm{N}=67)$ in Belgian prisons who were

\footnotetext{
${ }^{2}$ Belgian legislation gives each prosecutor the possibility to deny access to case files if he considers it inappropriate (e.g. for security reasons). This mostly applies to pending cases.
} 
asked to participate in the research. The potential sample size was largely reduced because of: (1) the limitation to only interview convicted offenders (not those under custody); (2) the fact that many of them are illegal in Belgium and are therefore expelled after a part of their punishment; (3) the prison administration data not being up-to-date; and (4) potential respondents refusing to cooperate. The interviews developed around a topic list, which is presented as appendix 2. The interviews dealt with four main issues: general introductory questions, topics concerning travelling and living routines, involvement in crime and criminal location choice.

Interviewing offenders of the same nationality and in the same language allowed us to have the same interpreter involved, creating a high level of uniformity throughout the interviews. It was made clear that the interview would deal with both their general background information and their criminal activities. The interviews were conducted in one of the prisons' separate rooms (rooms most often used for prisoners to meet their lawyers) with only the respondent, the interpreter and the researcher present. Most interviews took between 60 and 90 minutes. The respondents were asked whether the interview could be tape-recorded. If this was not the case, notes were taken.

Through face-to-face, semi-structured interviews with offenders, first hand information was obtained on starting points, target choices and directional motivations, including awareness space. These additional data were used in particular for assessing the offenders' target location choice (hypothesis 3).

The respondents were all male, between 22 and 45 years of age. Most of them were in their twenties (10 persons) or thirties (9). None had long-term employment. Most had worked only for a couple days a week and on a temporary and illegal basis (moonlighting). They had worked mostly in construction industry, horticulture, construction of exposition stands, selling cars, selling flowers, or begging. 


\section{Findings}

The unit of analysis here is offender-offence combination; what we call 'crime trips'. Both multiple offending and co-offending have been observed. Obviously, if we would have used crime trips for calculating the percentage of co-offending, we would have counted the offences committed by two offenders twice, by three offender three times, etc, as these are considered as separate crime trips. This would have lead to an overestimation of co-offending (only 26391 out of 67981 crime trips, or 38.8 per cent, are committed by a single offender). However, using crimes as a unit of analysis for this calculation, we find that 36853 out of 49736 crimes (74.1 per cent) are committed by a single offender.

We found 5187 out of 49736 (10.4 per cent) crimes to involve at least one Eastern European offender, while 38408 (77.2 per cent) crimes were committed by at least one Belgian perpetrator. Co-offending was more common for crimes involving Eastern European offenders (1882 crimes or 36.3 per cent) than it is for crimes committed by Belgian offenders (11047 crimes or 28.8 per cent).

A similar shortcoming was found when using crime trips for calculating the percentage of multiple offenders. Whereas only 19718 crime trips (29.0 per cent) were committed by one-time offenders, this counts offenders having committed two offences twice, etc. Looking at the offenders themselves, we found that 22047 out of 31979 offenders (68.9 per cent) have only committed one offence. Eastern European offenders (2550) commit 2.78 offences on average, while this is 2.09 for Belgian offenders. Given the layered structure of our data and an ICC of .55, we explored multiple offending and nesting within individuals in the further statistical tests.

Travelled distances are presented in table 1 . Generally, we observed an average travelled distance in Belgium of $19.1 \mathrm{~km}$ and a median distance of $7.2 \mathrm{~km}$ for all crime trips. 
The distances range from $.52 \mathrm{~km}$ to $276.23 \mathrm{~km}$ (which is about the largest distance that can be travelled within Belgium).

Next, we compared the travelled distances of Eastern European criminals with those travelled by other offenders. Eastern European criminals travel $34.7 \mathrm{~km}$ on average, while this is only $17.0 \mathrm{~km}$ for Belgian offenders. The Wald statistic shows that the difference between both groups is statistically significant $\left(\chi^{2}=811.88 ; \mathrm{df}=1 ; \mathrm{p}<.001\right)$.

(Table 1 about here)

The decay patterns, which are presented in figure 1, differ too. For easy interpretation and comparison, the distance in these decay curves are presented in classes of $10 \mathrm{~km}$. We observe a straightforward decay for Belgian offenders: over 60 per cent of the crimes are committed within $10 \mathrm{~km}$ from the registered residence, drastically declining afterwards. For Eastern European criminals, less than 35 per cent of the crime trips was committed within 10 $\mathrm{km}$ from the residence. There is a certain distance decay, but it is not as straightforward as it is for the first group. Furthermore, mobility of these offenders appears to rise again between 30 and $50 \mathrm{~km}$. The exact figures for this curve are given in Appendix 1.

(Figure 1 about here)

The study of anchor points of foreign offenders first reveals that not all residences or temporary residences are caught in crime databases. Assuming that only residences in Belgium or its neighbouring countries (the Netherlands, France, Germany, Luxembourg) may function as true anchor points, the police statistics reveal a low proportion of registered anchor points for Eastern European offenders, compared with Belgian criminals (Table 2). 
(Table 2 about here)

The proportion of missing data is higher for Eastern European offenders than it is for Belgian offenders. Taking into account the registered residences that are unlikely to function as anchor points (other countries than Belgium or its neighbours), the anchor point cannot be assessed for over 60 per cent of Eastern European offenders by using only police statistics.

We further investigated the direction of the offenders' crime trips. Offenders in our sample mostly resided in one of the main Belgian cities, albeit not always officially. They travelled considerable distances and left the city during their crime trips. Table 3 compares the population density of crime trips by Eastern European offenders and those by Belgian offenders. This represents the urban character of their targets.

(Table 3 about here)

Crime trips by Eastern European offenders tend to depart from more dense, urban areas than those of Belgian offenders. However, the target areas are less densely populated than those chosen by Belgian criminals. Wald statistics indicate that both averages differ statistically and therefore, both departure $\left(\chi^{2}=103.55 ; \mathrm{df}=1 ; \mathrm{p}<.001\right)$ and crime location $\left(\chi^{2}=9.30 ; \mathrm{df}=1 ; \mathrm{p}=.002\right)$ area population densities significantly differ between Belgian and foreign offenders.

Next, we assessed the wealth of the areas where crime trips begin and end (table 4). To gauge the affluence of both target and departure areas, we used an affluence index from the Belgian National Institute of Statistics. All municipalities are indicated by an affluence value based on the average income of the municipality's citizens. A value of 100 corresponds with the average in Belgium. 
(Table 4 about here)

The findings are quite comparable to those from the population figures: Eastern European offenders tend to depart from poorer urbanised areas and tend to offend in more wealthy, rural regions. The same trend can be noticed for Belgian offenders, although the differences are much more moderate. Wald statistics indicate that both differences in terms of wealth of departure $\left(\chi^{2}=93.69 ; \mathrm{df}=1 ; \mathrm{p}<.001\right)$ and target $\left(\chi^{2}=67.44 ; \mathrm{df}=1 ; \mathrm{p}<.01\right)$ areas are statistically significant.

\section{Case file analysis}

The case file analysis came up with similar results. Some offenders undertook short crime trips, but the majority of crime trips took them further away. In all case files the offenders have a large operation area that exceeds city borders and over $50 \mathrm{~km}$. In 15 case files the offenders did not offend in the city where they stay overnight and were therefore always mobile.

Although it is difficult to uncover the exact route that was followed; some offenders use their mobile phones during crime trips. Tracing this activity may link offenders to certain crimes and routes. These cases indicate that offenders use the motorway to reach their targets. It is quite remarkable that they travel such a distance without even considering closer targets.

Several types of anchor points have been observed. Only in three cases, there was a secondary anchor point that functioned as a convergence setting for criminals. No similar information was available for the other 23 cases. However, police investigations put most emphasis on offenders, not places. The chances are therefore that in a number of cases a 
convergence setting does exist, but that it may escape police attention because of a different focus and because police are able to picture the offenders even without assessing the convergence setting.

The residences that are encountered in the files are quite fixed. Only in one case do the offenders regularly move to other areas. In all other cases, the residences are stationary. In 18 cases, the premises are fixed, whereas in the other 7 cases, offenders do move but still remain in the same city or region. This basically implies that the anchor points can be regarded as stationary: given the large distances they cover during crime, the residential changes have little to no effect on the direction and length of the crime trips. Furthermore, crime travelling in some cases could be observed through mobile phone tracing. In one case, the offenders travelled back and forth during the night from a city in the south of Belgium to the coast area (over $150 \mathrm{~km}$ one way) to commit a couple of burglaries. As they regularly called each other on the phone, police forces could rather easily trace their travel route and time. Because of their speed and location during their calls, there is no other conclusion than that they used the motorway to travel.

In the vast majority of the case files (18), the offenders departed from large cities. In five cases, the offenders stayed in the border region, operating on both sides. Only in three cases the offenders lived elsewhere.

Most offenders develop spatial knowledge in ways that directly corresponds to criminal activity: often they go out scouting beforehand (15 cases), operate in the same neighbourhoods, targeting the same or nearby houses than they did before - so-called near repeat burglaries (Bernasco, 2008; Townsley, Homel, and Chaseling, 2003) (7 cases) or may even use maps to learn about the area ( 2 cases). However, only in two cases information has been gathered through activities that are completely independent from crime. 


\section{Offender interviews}

As with the case file analysis, various distance patterns are observed. Six interviewed offenders operate exclusively near their anchor point and may therefore be regarded as local offenders. The other respondents (15) are more mobile and cover larger areas. Ten interviewees did not operate at all in the area where they stayed overnight.

During the interviews, six offenders said they travelled around randomly and started looking for targets relatively close to their starting point, but ended up further because they found nothing suitable nearby. Two of them remarked at their surprise when they realised that they had travelled such distances. The other four did not consider their distances to be so far away.

I wasted a fortune on gasoline [...] I started to look around [in nearby municipalities...], but then a neighbour appeared or something [...]. A bit further, a roll-down shutter was brought up and so on [...] By the time I found a target, I had driven a lot (respondent b2)

Only two respondents have lived in more rural areas, while the others all stayed in one of Belgium's major cities. Most interviewed offenders (15) started their crime trips from the places where they also stayed overnight. Seldom was this known as their official residence. Often, they had slept with several others in small apartments owned by slumlords (10 persons). Others had managed to rent a temporary apartment for themselves (6 persons). A third type of anchor point was found for offenders who stayed overnight in less common places that were not mentioned in the official crime statistics: hotels (6 persons), railway stations (2), abandoned buildings (1) or a car (1). These places may evolve over time: people that first stay with others may later be able to rent an apartment by themselves ( 2 
respondents), while people sleeping in hotels may alternatively sleep at a friend's place or elsewhere (2 respondents).

Not always the same. First a couple of days in [city 1], then a couple of days in [city 2], and then back. (respondent b14)

In several cases, other places than home-in its broad interpretation as a sleeping place - function as anchor points. People meet at pubs (7), railway stations (2) and other public places (4). In these places, they make arrangements for future crimes and often initiate their crime trips. Some bars merely function as meeting places providing sufficient anonymity. In other cases, pub owners are actively involved in selling stolen goods or even take a coordinating role in crime.

Mostly we divided the loot [...] and then about an hour later back to the bar [...] and we talked to the owner of the pub to make a deal concerning the price. He bought about everything. (respondent a2)

It occurs that criminal organisations use non-profit organisations and their headquarters as cover for crime. Doing so has the advantage that people can walk in and out without looking suspicious, and compared to a regular pub, the non-profit organisation keeps out most unwanted visitors.

Seven offenders had no fixed anchor point. They alternated crime trips starting from home with crime trips that initiated at certain convergence settings. This hampers a clear assessment of the crime trip, as one cannot easily say which anchor point has been used for which crimes. 
Crimes outside the anchor point area may occur in other cities, but most popular locations are wealthy and rural areas. The offenders interviewed gave three main reasons for travelling outside the cities. First, they were at certain places to meet old friends or search for work ( 6 persons). In this case, they had non-criminal motives for travelling (it has only been the first time they went there). Hence, they still had little awareness about the area.

I went with a friend from [cityl] to [town], because he suggested to have a drink with someone he knew and lived there for a while. [...] Then we let him at the pub, because he had a wife and child waiting at home and we didn't want to get him involved [...] and we walked a bit and started burgling. (respondent b10)

Second, they indicated that rural areas offered more quiet to 'work in' (3 respondents). Instead of the crowded but rather anonymous cities, they chose to operate in regions where they expect to be seldom confronted with any possible guardians. The offenders explained that, for burglary, they particularly looked for houses that are secluded, so that their visibility would be low. In urban environments, these types of targets are rare. A third reason the respondents mentioned is the affluence of rural environments. Offenders indicated that they went to richer districts and that they often also took into account signs of wealth when choosing their actual targets (3 respondents). Six offenders were not able to give a particular reason for their target area selection. They drove around and operated randomly (5 persons) or acted together with someone else who made the decisions (1 respondent).

Given the mobility of the offenders in our sample, we are also interested in their awareness space. It turns out that they have few daily routines. They had only limited access to work and leisure activities and no extensively-developed awareness space. If they know the region where they operate, it is often because they have already committed other crimes in 
that region or because they have performed some reconnaissance, both of which can hardly be described as regular developments of spatial awareness.

\section{Discussion and conclusions}

This research aimed at investigating a number of observations with respect to offender mobility and its application to a sample of foreign offenders. Because these observations recur in many research papers, they have achieved the image of being general principles of offender mobility. Using both quantitative and qualitative methods we researched these principles on a sample of Eastern European criminals that were involved in property crime in Belgium (Western Europe). We tested whether: (1) they follow a distance decay pattern; (2) their crime trips start from home; and (3) they travel towards criminal opportunity structures.

In first instance, we investigated the distance patterns of foreign offenders. Our mixed data on Eastern European offenders in Belgium reveals that they cover large distances on average and travel more than twice as far than Belgian offenders do. This also has implications on the distance decay curve of crime by these offenders. A larger amount of crimes is located further away. Crime trips particularly cover between 30 and $50 \mathrm{~km}$. Such travelling is not always the result of a deliberate choice. Furthermore, the offenders do not always perceive such distances as large. This confirms Polisenska's (2008: 56) finding that "each offender understood the aspects of "close to home, far from home" in a different manner'.

As a second question, we wondered whether these offenders start their crime trips from home. Here, the use of crime statistics is rather problematic. These do contain addresses, but no reference is made to the places that actually serve as starting points for the crime trips. It 
appears that potential anchor points are only registered in just over one-third of cases with Eastern European offenders.

A number of offenders are still officially registered in their home country. For them, it is unlikely that they undertake a crime trip of over $2000 \mathrm{~km}$. Case file analysis and offender interviews indicate that they often use temporary residences in Belgium as anchor points. These are not incorporated in official crime statistics and may cause incorrect estimates of crime trips and patterns if not taken along in the analysis. Furthermore, offenders often meet in bars or other convergence settings (Felson, 2003) to start their crime trips. These settings are located in the same city where they stay overnight. This shows that the official home is not always the anchor point. Offenders may as well start from a temporary residence or a convergence setting. These convergence settings indicate the prevalence of co-offending. Bernasco (2006) revealed that co-offenders tend to operate nearby the residence of one of the offenders. Consequently, travel patterns may seem atypical for the other offenders, as their criminal activity space is not centred around their own home. Offenders in our sample mostly meet in convergence settings that are located in the city where all offenders live, while committing so-called 'outbound offences' (Van Daele and Vander Beken, 2011), leaving that city for criminal activity. Thus, the criminal activity space is neither located nearby one of the residences, nor around the convergence setting.

Thirdly, it is expected that these offenders travel in the direction of criminal opportunity structures. This turns out to be not the case at all. The offenders in our sample follow patterns and choose directions that are the reverse of what we may expect. They leave the opportunity structures where they stay to offend elsewhere. The reasons for choosing certain targets seem rational. They head for target areas where the rewards may be higher and the potential guardians lower. Previous research has found that most offenders operate in regions they know. It is in the areas they are aware of - hence the name awareness space (Brantingham 
and Brantingham, 1981) - that they search for targets (Bernasco, 2010; Bernasco and Nieuwbeerta, 2005; Brantingham and Brantingham, 1993b; Palmer, Holmes, and Hollin, 2002; Rengert and Wasilchick, 1985). As a side effect of the finding that offenders in our sample head in the direction of rural areas, we also find that their spatial awareness is limited, both near their anchor point and further away. For them, there is little value to operate in their neighbourhoods, because they know neither the area around their anchor points nor the regions that are located further away. They seem to be bound only to a minor extent to this awareness space and consider abstract elements (such as 'rich areas' or 'quiet' in which to work) in their target selection.

We always went to the northern part of Belgium [...]. There is just more to get, it is more wealthy (respondent b3)

Not in [city name] itself. It's too crowded there, too much police. In smaller villages, when the cops come after you, you can still run away through the fields or from garden to garden. (respondent b6)

Our research demonstrates that some of the so-called principles of offender mobility do not apply to foreign, specifically, Eastern European offenders. Although the proportion of such offenders may be limited, the findings hold some important implications and points of interest for environmental criminology. Regarding the travelled distances, most researchers find that offenders stay very close to home. However, most of these studies have been conducted in cities: Philadelphia, USA (Turner, 1969; White, 1932); The Hague, Netherlands (Bernasco, 2006); Perth, Australia (Clare, Fernandez and Morgan, 2009); or Norfolk, Virginia, USA (White, 1999). Studies that only consider what happens within one city's 
boundaries are simply unable to observe larger crime trips. Comparing intra-city crime trips with a broader perspective, Wiles and Costello (2000) found crime trips of $3 \mathrm{~km}$ within Sheffield (UK), although this adds up to $11 \mathrm{~km}$ when they included crime trips starting in Sheffield and ending outside the city in their analysis. This demonstrates that focusing only on intra-city patterns neglects some of the existing crime patterns. As such, the mobile offenders mentioned in ethnographic research (Bennett and Wright, 1984; Cromwell, Olson, and Avary, 1991; Maguire and Bennett, 1982; Mawby, 2007; Polisenska, 2008; Shover, 1972) may be more common than traditional intra-city research may indicate. This possibility is certainly worth exploring. Researchers should at least take into account the geographic limits of their data and how this may bias their results.

Concerning the anchor points, Rengert $(1992,2004)$ states that home is too often considered the starting point of crime trips. Nevertheless, research based on police data mostly assumes that offenders depart from home. In geographic profiling (Canter, 2003; Canter and Youngs, 2008b, 2008c; Rossmo, 1997, 2000; Rossmo and Rombouts, 2008), home is still given a central role, while few researchers (Bernasco, 2006; Felson, 2006a, 2006b; Wiles and Costello, 2000) focus on secondary anchor points, such as friends' homes or convergence settings.

Finally, our research has implications for the study of crime locations. Whereas cities are considered the main opportunity structures for crime, containing both crime generators and crime attractors (Brantingham and Brantingham, 1995; Pyle et al., 1974), offenders may consider it worthwhile to travel elsewhere and even to leave the cities where they start. According to Wiles and Costello (2000), one may overestimate the crime import of cities, again because of the fact that studies on offender mobility focus on crime within certain cities. As such, researchers become aware of criminals living outside cities and offending within the area. Yet, they neglect those offenders who move the other way around, because their crimes 
are not included in their sample. Despite the important role of cities for crime, the study of outbound offending (for example, Van Daele and Vander Beken, 2011) is often neglected. Still it deserves attention by criminologists, as the aim is to understand crime patterns in general and research should not be limited to sampling only from selected cities.

Furthermore, pattern theory and the principle of awareness space (Brantingham and Brantingham, 1981, 1993a, 1993b) may play an important role in offenders' criminal location choice: awareness of potential targets and risks helps offenders and such awareness is developed through non-criminal routine activities. Such awareness is not static. Experienced offenders are better in assessing cues that have an impact on the attractiveness and success of potential targets (Brown and Bentley, 1993; Nee and Meenaghan, 2006; Taylor and Nee, 1988; Wright, Logie, and Decker, 1995). As such, spatial awareness can be further developed with growing expertise. However, this principle assumes a basic level of spatial awareness that can then eventually evolve. Our research has demonstrated that such a rudimentary awareness should not be taken for granted. Foreign offenders lack such an awareness and therefore do not operate according to this principle. Alternatively, they search for targets based on some abstract opinions or even in a completely random way. Due to the lack of such an awareness space, they may plan their offences more deliberately and not commit crimes as and when opportunities arise in their awareness space, as is often the case for other offenders. Furthermore, they are used to travel larger distances, as they have travelled from Eastern to Western Europe. As such, their 'routine distances' may differ from those of local offenders (Polisenska, 2008).

The research here uses several complementary methods to extend the knowledge on offender mobility. The results of these three methods generally agree. The amount of case files and interviews could be extended, although the sample size is in line with other ethnographic research on burglary (Cromwell et al., 1991; Polisenska, 2008; Wright and 
Logie, 1988). Furthermore, we have opted for an approach using multiple methods with smaller samples instead of one method with a larger sample. The findings of this research may put the general applicability of three much-encountered mobility findings in a different perspective. Yet, other scholars have previously pointed in the same direction (Morselli and Royer, 2008; Polisenska, 2008; Wiles and Costello, 2000). Together with their earlier work, this analysis demonstrates that the study of solely intra-city crime trips conceals the existence of other crime patterns. 


\section{Bibliography}

Bennett, T., and Wright, R. (1984). Burglars on burglary. Aldershot: Gower.

Bernasco, W. (2006). Co-offending and the choice of target areas in burglary. Journal of Investigative Psychology and Offender Profiling, 3(3), 139-155.

Bernasco, W. (2008). Them again? same-offender involvement in repeat and near repeat burglaries. European Journal of Criminology, 5(4), 411-431.

Bernasco, W. (2009). Foraging Strategies of Homo Criminalis: Lessons From Behavioral Ecology. Crime Patterns and Analysis, 2, 5-16.

Bernasco, W. (2010). A sentimental journey to crime: effects of residential history on crime location choice. Criminology, 48(2), 389-417.

Bernasco, W., \& Nieuwbeerta, P. (2005). How do residential burglars select target areas? A new approach to the analysis of criminal location choice. British Journal of Criminology, 45(3), 296315.

Bottoms, A. E., \& Wiles, P. (1992). Explanations of Crime and Place. In D. J. Evans, N. R. Fyfe \& D. T. Herbert (Eds.), Crime, Policing and Place: Essays in Environmental Criminology (pp. 1135). London: Routledge.

Brantingham, P., \& Brantingham, P. (1981). Notes on the geometry of crime. In P. Brantingham \& P. Brantingham (Eds.), Environmental criminology (pp. 27-54). Beverly Hills: Sage.

Brantingham, P., \& Brantingham, P. (1993a). Environment, routine and situation: toward a pattern theory of crime. In R. Clarke \& M. Felson (Eds.), Routine Activity and Rational Choice (pp. 259-294). New Brunswick: Transaction Publishers.

Brantingham, P., \& Brantingham, P. (1993b). Nodes, paths and edges: considerations on the complexity of crime and the physical environment. Journal of Environmental Psychology, 13(1), 3-28.

Brantingham, P., \& Brantingham, P. (1995). Criminality of place: crime generators and crime attractors. European Journal on Criminal Policy and Research, 3(3), 5-26.

Brantingham, P. J., \& Brantingham, P. L. (2008). Crime pattern theory. In R. Wortley \& L. Mazarolle (Eds.), Environmental criminology and crime analysis (pp. 78-94). Devon: Willan Publishing.

Brown, B., \& Bentley, D. (1993). Residential burglars judge risk: the role of territoriality. Journal of Environmental Psychology, 13(1), 51-61.

Bruinsma, G. J. N. (1999). Criminaliteitsbeeld van Twente in 1995, 1996 en 1997. Enschede: IPIT.

Canter, D. (2003). Mapping murder: secrets of geographic profiling. London: Virgin Publishing.

Canter, D., \& Gregory, A. (1994). Identifying the residential location of serial rapists. Journal of the Forensic Sciency Society, 34(3), 169-175.

Canter, D., \& Larkin, P. (1993). The environmental range of serial rapists. Journal of Environmental Psychology, 13(1), 63-69.

Canter, D., \& Youngs, D. (2008a). Geographical offender profiling: applications and opportunities. In D. Canter \& D. Youngs (Eds.), Applications of geographical offender profiling (pp. 3-24). Aldershot: Ashgate.

Canter, D., \& Youngs, D. (Eds.). (2008b). Applications of geographical offender profiling. Aldershot: Ashgate.

Canter, D., \& Youngs, D. (Eds.). (2008c). Principles of geographical offender profiling. Aldershot: Ashgate.

Capone, D., \& Nichols, W. (1975). Crime and distance: an analysis of offender behavior in space. Proceedings of the Association of American Geographers, 7(1), 45-49.

Clare, J., Fernandez, J., \& Morgan, F. (2009). Formal evaluation of the impact of barriers and connectors on residential burglars' macro-level offending location choices. Australian and New Zealand Journal of Criminology, 42(2), 132-158.

Cohen, L., \& Felson, M. (1979). Social change and crime rate trends: a routine activity approach. American Sociological Review, 44(4), 588-608.

Cornish, D., \& Clarke, R. (Eds.). (1986). The reasoning criminal : rational choice perspectives on offending. New York: Springer. 
Cromwell, P., Olson, J., \& Avary, D. A. W. (1991). Breaking and entering: an ethnographic analysis of burglary. Newbury Park: Sage.

Eck, J. E., \& Weisburd, D. (Eds.). (1995). Crime and place. Monsey: Criminal Justice Press.

Elffers, H. (2004). Decision models underlying the journey to crime. In G. J. N. Bruinsma, H. Elffers \& J. W. De Keijser (Eds.), Punishment, Places and Perpetrators. Developments in Criminology and Criminal Justice Research (pp. 182-197). Devon: Willan Publishing.

Felson, M. (1986). Linking criminal choices, routine activities, informal control and criminal outcomes. In D. Cornish \& R. V. Clark (Eds.), The reasoning criminal: rational choice perspectives on offending (pp. 119-128). New York: Springer.

Felson, M. (2003). The process of co-offending. In M. Smith \& D. Cornish (Eds.), Theory for Practice in Situational Crime Prevention (Vol. 16, pp. 149-167). Monsey: Criminal Justice Press.

Felson, M. (2006a). Crime and nature. Thousand Oaks: Sage.

Felson, M. (2006b). The ecosystem for organized crime. Helsinki: Heuni.

Felson, M. (2008). Routine activity approach. In R. Wortley \& L. Mazarolle (Eds.), Environmental criminology and crime analysis (pp. 70-77). Devon: Willan Publishing.

Felson, M., \& Cohen, L. (1980). Human ecology and crime: a routine-activity approach. Human Ecology, 8(4), 389-406.

FOD Justitie, FOD Kanselarij van de Eerste Minister, \& FOD Binnenlandse zaken. (2007). De aanpak van de rondtrekkende dadergroeperingen: een actualisatie. Brussel: Federale Politie.

Ghosh, B. (1951). Random distances within a rectangle and between two rectangles. Bulletin of Calcutta Mathematical Society, 43(1), 17-24.

Hesseling, R. (1992). Using data on offender mobility in ecological research. Journal of Quantitative Criminology, 8(1), 95-112.

Hodgson, B., \& Costello, A. (2006). The prognostic significance of burglary in company. European Journal of Criminology, 3(1), 115-119.

Hox, J. (2010). Multilevel analysis: techniques and applications (2 ed.). New York: Routledge.

Kocsis, R., Cooksey, R., Irwin, H., \& Allen, G. (2002). A further assessment of 'circle theory' for geographic psychological profiling. Australian and New Zealand Journal of Criminology, 35(1), 43-62.

Maguire, M., \& Bennett, T. (1982). Burglary in a dwelling: the offence, the offender and the victim. London: Heinemann.

Mawby, R. (Ed.). (2007). Burglary. Aldershot: Ashgate.

Morselli, C., \& Royer, M.-N. (2008). Criminal mobility and criminal achievement. Journal of Research in Crime and Delinquency, 45(1), 4-21.

Nee, C., \& Meenaghan, A. (2006). Expert decision making in burglars. British Journal of Criminology, 46(5), 935-949.

Palmer, E., Holmes, A., \& Hollin, C. (2002). Investigating burglars' decisions: factors influencing target choice, method of entry, reasons for offending, repeat victimisation of a property and victim awareness. Security Journal, 15(1), 7-18.

Phillips, P. (1980). Characteristics and typology of the journey to crime. In D. Georges-Abeyie \& K. Harries (Eds.), Crime: a spatial perspective (pp. 167-180). New York: Columbia University Press.

Polisenska, A. V. (2008). A qualitative approach to the criminal mobility of burglars: questioning the 'near home' hypothesis. Crime Patterns and Analysis, 1(1), 47-60.

Porter, M. (1996). Tackling cross border crime. London: Police Research Group, Home Office.

Pyle, G., Hanten, E., Williams, P., Pearson, A., \& Doyle, G. (1974). The spatial dynamics of crime. Chicago: University of Chicago.

Rattner, A., \& Portnov, B. (2007). Distance decay function in criminal behavior: a case of Israel. Annals of Regional Science, 41(3), 673-688.

Rengert, G. (1992). The journey to crime: Conceptual foundations and policy implications. In D. Evans, N. Fyfe \& D. Herbert (Eds.), Crime, Policing and Place: Essays in environmental criminology (pp. 109-117). London: Routledge. 
Rengert, G. (2004). The journey to crime. In G. Bruinsma, H. Elffers \& J. De Keijser (Eds.), Punishment, Places and Perpetrators: Developments in Criminology and Criminal Justice Research (pp. 169-181). Cullompton: Willan Publishing.

Rengert, G., Piquero, A., \& Jones, P. (1999). Distance decay reexamined. Criminology, 37(2), 427446.

Rengert, G., \& Wasilchick, J. (1985). Suburban burglary: a time and a place for everything. Springfield: Thomas.

Reppetto, T. (1974). Residential crime. Cambridge: Ballinger.

Rhodes, W., \& Conly, C. (1981). Crime and mobility: an empirical study. In P. Brantingham \& P. Brantingham (Eds.), Environmental Criminology (pp. 167-188). Beverly Hills: Sage.

Rossmo, K. (1995). Place, space and police Investigations: hunting serial violent criminals. In J. Eck \& D. Weisburd (Eds.), Crime and place (pp. 217-235). Monsey: Criminal Justice Press.

Rossmo, K. (1997). Geographic profiling. In J. Jackson \& D. Bekerian (Eds.), Offender profiling: theory, research and practice (pp. 159-175). Chichester: Wiley.

Rossmo, K. (2000). Geographic profiling. Boca Raton: CRC Press.

Rossmo, K., \& Rombouts, S. (2008). Geographic profiling. In R. Wortley \& L. Mazerolle (Eds.), Environmental criminology and crime analysis (pp. 136-149). Cullompton: Willan publishing.

Sarangi, S., \& Youngs, D. (2006). Spatial patterns of Indian serial burglars with relevance to geographical profiling. Journal of Investigative Psychology and Offender Profiling, 3(2), 105115.

Shover, N. (1972). Structures and careers in burglary. Journal of criminal law, criminology and police science, 63(4), 540-549.

Smith, W., Bond, J., \& Townsley, M. (2009). Determining how journeys-to-crime vary: measuring inter- and intra-offender crime trip distributions. In D. Weisburd, W. Bernasco \& G. Bruinsma (Eds.), Putting crime in its place: units of analysis in geographic criminology (pp. 217-236). New York: Springer.

Taylor, M., \& Nee, C. (1988). The role of cues in simulated residential burglary: a preliminary investigation. British Journal of Criminology, 28(3), 396-401.

Townsley, M., Homel, R., \& Chaseling, J. (2003). Infectious burglaries: a test of the near repeat hypothesis. British Journal of Criminology, 43(3), 615-633.

Townsley, M., \& Sidebottom, A. (2010). All offenders are equal, but some are more equal than others: variation in journeys to crime between offenders. Criminology, 48(3), 897-917.

Turner, S. (1969). Delinquency and distance. In T. Sellin \& M. Wolfgang (Eds.), Delinquency: Selected Studies (pp. 11-26). New York: Wiley.

Van Daele, S. (2010). Mobility and distance decay at the aggregated and individual level. In M. Cools, B. De Ruyver, M. Easton, L. Pauwels, P. Ponsaers, G. Vande Walle, T. Vander Beken, F. Vander Laenen, G. Vermeulen \& G. Vynckier (Eds.), Safety, societal problems and citizens' perceptions: new empirical data, theories and analyses (pp. 41-59). Antwerp: Maklu.

Van Daele, S., \& Vander Beken, T. (2011). Outbound offending: the journey to crime and crime sprees. Journal of Environmental Psychology, 31(1), 70-78.

Van Koppen, P., \& De Keijser, J. (1997). Desisting distance decay: On the aggregation of individual crime trips. Criminology, 35(3), 505-515.

Van Koppen, P., \& Jansen, R. (1998). The road to robbery: travel patterns in commercial robberies. British Journal of Criminology, 38(2), 230-246.

White, C. (1932). The relations of felonies to environmental factors in Indianapolis. Social Forces, 10(4), 498-509.

White, G. (1999). Neighborhood permeability and burglary rates. Justice Quarterly, 7(1), 57-67.

Wilcox, P., Land, K. C., \& Hunt, S. A. (2003). Criminal circumstance : A dynamic multicontextual criminal opportunity theory. New York: Aldine de Gruyter.

Wiles, P., \& Costello, A. (2000). The 'road to nowhere': the evidence for travelling criminals. London: Home Office.

Wright, R., \& Logie, R. (1988). How young house burglars choose targets. The Howard Journal of Criminal Justice, 27(2), 92-104. 
Wright, R., Logie, R., \& Decker, S. (1995). Criminal expertise and offender decision making: an experimental study of the target selection process in residential burglary. Journal of Research in Crime and Delinquency, 32(1), 39-53. 
Table 1: Travelled distances

\begin{tabular}{|c|c|c|c|c|}
\hline Nationality & Mean (km) & Median (km) & Std. deviation & Std. E. mean \\
\hline Eastern European (N=7078) & 34.69 & 22.10 & 34.93 & .32 \\
\hline Belgian (N=51385) & 16.96 & 6.63 & 25.67 & .11 \\
\hline
\end{tabular}

Figure 1: Distance decay patterns

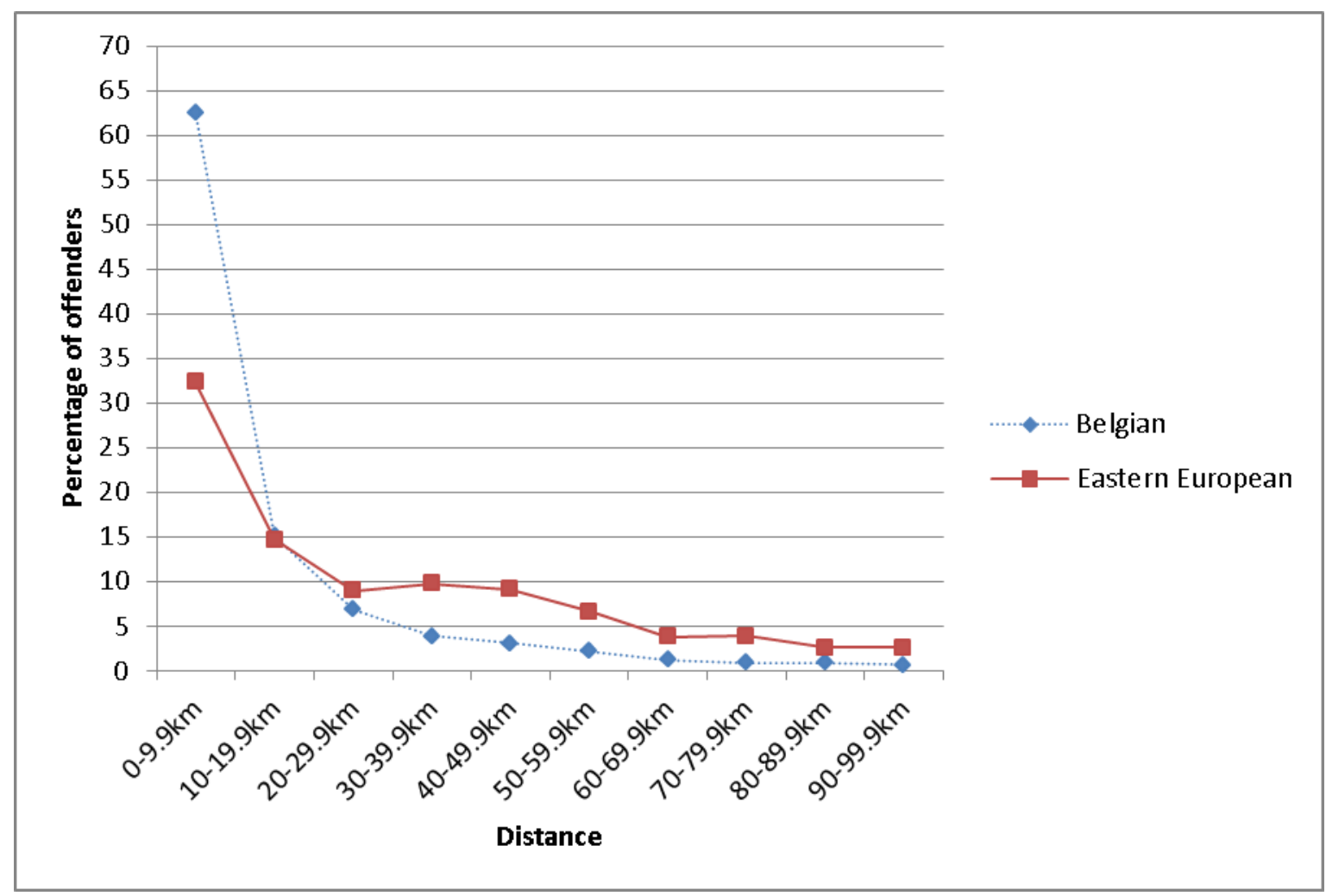

Table 2: Anchor point registration in police database (unit=offender)

\begin{tabular}{|l|c|c|}
\hline \multicolumn{1}{|c|}{ Country of residence } & Belgian offenders & Eastern European offenders \\
\hline \hline Belgium & $24561(56.8 \%)$ & $2518(34.5 \%)$ \\
\hline Neighbouring countries & $167(0.4 \%)$ & $130(1.8 \%)$ \\
\hline Other countries & $54(0.1 \%)$ & $408(5.6 \%)$ \\
\hline Missing & $18455(42.7 \%)$ & $4233(58.1 \%)$ \\
\hline \hline
\end{tabular}




\begin{tabular}{|l|c|c|}
\hline \hline Total N & $43237(100.0 \%)$ & $7289(100.0 \%)$ \\
\hline
\end{tabular}

Table 3: Average population density of departure and target areas (Belgian residences)

\begin{tabular}{|l|l|l|}
\hline & Belgian offenders & Eastern European offenders \\
\hline Departure area & 1837.6 & 4079.8 \\
\hline Target area & 1520.6 & 1421.2 \\
\hline
\end{tabular}

Table 4: Average affluence index of departure and target areas

\begin{tabular}{|l|l|l|}
\hline & Belgian offenders & Eastern European offenders \\
\hline Departure area & 95.6 & 89.7 \\
\hline Target area & 97.4 & 102.4 \\
\hline
\end{tabular}

Appendix 1: Distance decay curve (figure 1)

\begin{tabular}{|l|c|c|c|c|}
\hline & \multicolumn{2}{|c|}{ Belgian offenders } & \multicolumn{2}{c|}{ Eastern European offenders } \\
\hline & $\mathrm{N}$ & $\%$ & $\mathrm{~N}$ & 32.3 \\
\hline $0-9.9 \mathrm{~km}$ & 32155 & 62.6 & 1040 & 14.7 \\
\hline $10-19.9 \mathrm{~km}$ & 7781 & 15.1 & 637 & 9.0 \\
\hline $20-29.9 \mathrm{~km}$ & 3559 & 6.9 & 695 & 9.8 \\
\hline $30-39.9 \mathrm{~km}$ & 2025 & 3.9 & 641 & 6.1 \\
\hline $40-49.9 \mathrm{~km}$ & 1571 & 3.1 & 469 & 3.8 \\
\hline $50-59.9 \mathrm{~km}$ & 1113 & 2.2 & 269 & 3.9 \\
\hline $60-69.9 \mathrm{~km}$ & 635 & 1.2 & 273 & 2.6 \\
\hline $70-79.9 \mathrm{~km}$ & 472 & 0.9 & 185 & 2.6 \\
\hline $80-89.9 \mathrm{~km}$ & 448 & 0.9 & 393 & 5.6 \\
\hline $90-99.9 \mathrm{~km}$ & 382 & 0.7 & 2.4 & \\
\hline \hline $100+$ & 1242 & & & \\
\hline
\end{tabular}




\begin{tabular}{|l|l|l|l|l|}
\hline Total N & 51383 & 100.0 & 7078 & 100.0 \\
\hline
\end{tabular}

Appendix 2: interview topic list

Non-threatening introductory questions:

How long have they been in Belgium

Where do they come from

How was the trip arranged

Where they accompanied by others

What were the reasons for coming to Belgium.

Travelling as a routine activity:

Have they travelled to other countries as well

Did they know people beforehand in Belgium

Where have they lived

What did their daily activities look like

Where they able to work here

Criminal involvement:

How many crimes have they committed

During which time span

Where other offenders involved as well

How are eventual arrangements made with co-offenders

Where do they meet the others 
Criminal location choice and awareness space:

Where are the crimes committed

Do they remember the places where they have been

Have they been there before

Was there a particular reason for targeting that area

Which transport means are used

Which targets are preferred (target type) and why

Which houses (in case of burglary) are preferred and why 